\title{
SOCIAL DETERMINANTS OF PROFESSIONAL ETHICS AMONG WORKERS IN INDUSTRIAL UNITS (A CASE STUDY OF INDUSTRIAL WORKERS IN ARDABIL)
}

\author{
Davoud Abdollahi $^{\text {a* }}$, Aliathar Ghaffari ${ }^{\mathrm{b}}$, Seyed Hassan Tayyar ${ }^{\mathrm{c}}$ \\ a. Ph.D. in Sociology, Lecturer Science and Research Branch, Islamic Azad University, Ardabil \\ b. M.S. student of Social Research, Islamic Azad University, Branch of Khalkhal \\ c. M.S. graduated in Industrial Engineering
}

\begin{abstract}
Professional ethics is a factor that under influence of external factors and with the help of individual conscience causes adherence (Dos and Don'ts) in a person. As Professional ethics be properly guided and strengthened by social or environmental elements, consequently, its effects will appear on the output or final product in a desirable way. This study examines the social influencing factors on the individual's level of professional ethics in the workplace. Data gathering tool is questionnaire; Type of research is causal comparative and the research sample is consisted of 400 workers in the industrial zones Number One and Number Two of Ardabil. There search instrument was researcher made questionnaire (including 78 questions), interview and also observation. Findings show that socio-cultural factors primarily and individual-personality factors in second, affect the person's work ethics. In addition, Social factors such as intimate relationships, Gender, education and skills, income, religious beliefs and job stability, has a positive impact on a person's work ethics.
\end{abstract}

Keywords: Professional ethics, commitment, work, sex, religion, income

\section{Introduction}

Working is the important and constructive element of individuals and society. Since human being is a social and collaborative creature, not competitive, militant and aggressive, confirmation of this subject is the capacity that humans seek in bonding with their fellows to achieve their common goals. Appropriateness of the job with other careers in each unit is considered as an effective strategy in

* Correspond Author 
maintaining the human resources. A major part of human social needs, such as respect and communication, are met in the workplace; where people can meet and talk to each other and share their experiences. Workers of manufacturing units and enterprises are no exception to this rule. When they are treated with respect and have the opportunity to comment and participate in all aspects of the work, to the strictest sense of the word, as a result, they will show appropriate and satisfactory responses. These responses will be shown desirably in the company's output, in the form of quality goods and services produced. In the economic spheres of the world of capitalism, companies and manufacturing units are highly competitive to attract and keep customers. Professionals and senior managers of manufacturing enterprises and organizations believe that their companies' success and stability is depended on respecting the customers and responding appropriately to the expectations.

Undoubtedly, such success is impossible without proper training of staff and line personnel, in a way that everyone in any levels of activity, confirms to occupational standards and professional norms in an appropriate manner.

\section{Research Problem}

One of the fundamental and strategic goals of any business (manufacturing, servicing, companies, factories, offices, and organizations) is customers or client's trust and continuous interaction with that business. These important factors happen, when highest product or services quality standards are met; some cases to mention are (compliance with professional standards such as commitment to quality, how to interact with customers, type of services provided and their quality level, and satisfaction of the customer or client, etc.), under these conditions the element of social capital is generated and in its shadow, mutual satisfaction and commitment of customers to the manufacturing or servicing business are formed (such as loyalty to the company's products or services, introducing it to other customers, respecting the brand or corporate identity).

Economics has proven that the final value of goods or services is determined not only by the amount of work done, but also by the quality of the work that has been done. In other words, professional norms that are sometimes referred to as commitment or professional ethics, such moral or ethical norms will be manifested in the form of product quality (product or services provided).Undoubtedly, analyzing and explaining the several factors that affect professional ethics (occupational) of employees in a manufacturing or servicing organization is an important and valuable task. Researches of this kind can be very effective in development and progress of our Islamic Iran. Stemming on social factors associated with the work ethics and professionalism in particular, manufacturing businesses and companies, can have effective results on the quality of goods and services and finally in dynamism of national production. Social factors associated with compliance with the norms of professional ethics are numerous; Cases such as occupational training in family, school, peers, media, subcultures, work culture and etc., each of them can be correlated with job commitment directly or indirectly. The main question of this study is that "What are the social factors associated with occupational and functional ethics in the industrial zones of Ardabil, and How, and by means of what proper scientific solutions, these factors can be strengthened and used for the more dynamism of these economic units, which will ultimately lead to the prosperity of the national production".

\section{Background}

Joseph Rowntree foundation in 1991 published the findings of Job insecurity and work intensification survey. The survey included numerous interviews with 340 British employees from production line workers to senior managers. This study was designed to investigate levels of job in security and its impact on working environment, family and societies. This study showed that with less features of the 
bureaucratic organizational structures and distribution of decision making throughout the workplace, the workers are expected to assume much more responsibility. Considering the results of the Rowntree foundation research, it seems that job in security as one of the effective components of occupational commitment, can have a significant impact on the efficiency of the work and the final product.

Kavian (2004) in a research entitled "The Survey about Labor Ethic in Isfahan's Zob-Ahan", bases his main research question on the main concern of the authorities on weakness of work ethics. Based on the Marxist theories, he believes that the weakness of working ethics is a result of alienation of the workers in industrial societies. Because according to The Marxist sociologists, workers consider working as an external affair and they have no sense of satisfaction from their work. The result shows that factors such as education, amount of salary and years of service, Attachment to work and etc., as crucial elements, affect the working ethics.

Chalabi (2006) in a study entitled "The Survey of Work Ethic in Three Cities of Iran" emphasizes on the ethical and cultural dimensions of work. It is noticeable that while the cultural dimension of ethics gives direction to the actor's action towards others and community, social dimension of ethics provides emotional energy to the actor's action, that is focused on the rights of others and community. Levels of sense of duty and commitment to the ethical principles regarding the community are dependent on the social strength of the community. The research method is essentially a survey with a sample size of 2160 people. The sample includes employees of the governmental organizations, semi-governmental organizations, cooperatives and more.

M.Golparvar and H.R.Oreizi (2008) in an article titled "Meta-Analysis of the Relationships among the Dimensions of Organizational Commitment and Job Alternative, Tendency to Remain and Turnover", performing 15 studies, have studied the total sample size of 4129 people. The results indicate that there is lowest correlation among these three dimensions of tendency to remain, turn over and job alternative, with affiliation commitments, whereas, the most correlation is with exchange commitment and then identification commitment.

Safarnia (2008) in a research entitled "Investigation of the Effective Factors on Creation and Enforcement of Organizational Commitment among the Public Bank Staff", investigates the influencing factors such as job security, participation in ownership, participation in goal setting and participation in decision making, on the organizational commitment of the staff of public banks. The results indicated that the research hypotheses about the factors of participation in organizational decision making, job security, participation in goal setting and participation in ownership, with 95\% confidence level, are the important factors on the creation and enforcement of organizational commitment in the public bank's staff.

\section{Literature review}

The term "ethics" has many applications. Sometimes it is description of mood or behavior, and sometimes it is a systematic knowledge. In the first application, both the internal state and Ego Queen can be distinguished from communicative behavior. Gharamaleki (Gharamaleki, 2009, pp. 8-9)in all of his works has defined ethics as personal and interpersonal communicative behaviors with respect to the other side's rights.

There are two distinct approaches to ethics: Professional ethics and applied ethics. Considering the distinction between theoretical ethics and applied ethics, on the one hand, and the distinction between theoretical ethics and ethics philosophy, on the other hand, is necessary. Ethics, in both of theoretical and practical tendencies, expresses the Do's and Don'ts, responsibilities and moral virtues. (Gharamaleki, 2009, pp. 10-11) 
Considering the above, Faith, is one of the internalized and key elements of an individual in applied ethics subject. A person, as the main and determinant factor, can play a significant role in operating the professional ethics. Strengthening individual religious beliefs enhances a person's commitment and professional ethics as a business person and results in greater efficiency of him.

A society which demands social development, in the cultural teleology of the work, is expected to have a positive consideration towards the four faces (Activity, Diagnosis, The ultimate goal of the work, The claim of the work). It is expected that the society culture, do not consider working due to greed, but consider it well per se, and as a substantive value. The culture of such a society, does not consider allocation of energy to work, as a kind of energy loss, but rather consider it as devoting energy or a kind of righteousness and piety. (Chalabi, 2006, pp. 140-141)

In the tradition of Kant, morality is considered to be synonymous with being rational. Ethical duty of man arises from the demand of reason. In other words, the origin of ethics is in the intellect of the rational beings. Ethical practice is like mathematical practice. Both types of actions are based on the reason (intellect). Thus the key features of the reason are: consistency, universality and priori. This approach regards moral command as a definite issue that is based on duty or essential commitment, and requirement of this commitment lies in the nature of reason or in the rational persuasion. (ibid, 2006, pp. 130-131)

The main feature of modern societies, professionalism, is forcing people to communicate with each other and this makes their connections stronger. These connections help forming a group morality in division of labor. These people become aware of their dependence on society and the forces that control and contain them. Durkheim wrote about it in asuccinct phrase: "Once the division of labor became the source of solidarity in society, at the same time, it became the basis of moral order".(Delaney, 2008, pp. 144-145) This moral order is the basis of cooperation in work and working sets to achieve the ultimate desirable goal.

Saint Simon emphasis on the moral order of society shows itself in Durkheim's thoughts. They both relate the extensive division of labor with common beliefs, to moral order that guarantees the social integration. In addition, they both consider the society according to thoughts or common beliefs. They both consider the definition of appropriate ethical system, as their responsibility. This ethical system undertakes task of uniting the classes and occupational groups together for a common goal. (Sabouri, 2004, pp. 28-29) Indeed, from the perspective of both thinkers, moral and value systems, cause an alliance and a sense of responsibility towards the society or reference group; it can be used as a tool for increasing desire and attachment to one's job and work environment.

The importance and value to worldly asceticism recommends the believers (followers) that they see the world as a source of pleasure and do their jobs as the best in the world. With this method the believer would be faithful to the will of God and complies with and surrender it at best. Weber's famous analysis of the concept (Beruf) is familiar to everyone: Luther, in his translation of the Bible, has used one word to describe the concept of (Profession) and (Vocation). Weber concludes here that the idea of "if professional life be guided properly will lead to sanctify the divine kingdom" was in Luther's beliefs. (Boudon, 2004, pp. 54-55)

Sabouri (2004, pp. 18-21) quoting from Kont, believes that it is the moral authority which creates beliefs, attitudes and thoughts that form the foundation of social order. Kont believes that the moral order is more praise worthy than secular order. He argues that the emphasis on the secular order, the economic wealth and social power is not sufficient for the survival of society. And Survival of and social order is possible only with an emphasis on moral order. Considering Kont's theory, for social order, moral authority as one of the pillars of social stability must be strengthened.

To reach the final destination of a complex production system, it is necessary to have order in that system and we can guide the system members by highlighting the spiritual beliefs and ideas to achieve development. 
Thompson quoting Durkheim noted that economic exchange in modern division of labor is based on contracts and contracts require a priori moral framework, and this framework cannot be exchanged (Thompson, 2009, pp. 114-115).

For us, social development without the kind of character growth is not possible, at the same time without the development of structural personality development, for the majority, creative, conscious and voluntary participation is unimaginable (Chalabi, 2005, pp. 225-226). In fact, people who like to participate are the creative part of a developed society. These people try to participate in society and play a positive role that fits their dignity.Thus, Durkheim in sociology of morality Plan, considers three social elements for ethics: emotional bonding, self-regulation, autonomy and knowledge (Chalabi, 2006, pp. 129-132).

So in a so called strong society, with a powerful empathy and collective identity, there is much sense of responsibility towards compliance with ethical rules. In fact, in terms of methodology, this level of strength can be traced in the individual (micro) and social (macro) levels respectively with the loyalty of the members (Chalabi, 2006, pp. 134-135). To increase and strengthen based on strengthening collective identity, Taylor suggests ways to standardize workplace conditions by collected-centered approach based on relationships.

Taylor and colleagues offer the followings to develop human relationships and increase the productivity of labor:

- Improving communication techniques between staff

- Physical and mental rest

- Recognizing the responsibility and supervising factors

- Efforts to improve workplace and make it compatible with health and hygiene conditions (Tehrani, 2010, pp. 141-142)

So absence or weakness of social cohesion, integration and generalized consensus, at the same time weakens the working commitment in society; and this means poor ethics in practice in a whole society level. (Chalabi, 2006, pp. 138-139)In a study using the score of "Job Description" by Smith P.C done in French labor study, five types of relations that may affect job satisfaction fashion were considered: the relationship with their supervisors, relationships with colleagues, relationships with work itself, wages and the possibility of job promotion (Tavassoli, 2006, pp. 154-155).

\section{Hypotheses}

- There is a positive relationship between income and professional ethics.

- There is a direct relationship between the intimate relationships (friendship) and professional ethics in the workplace.

- There is a positive relationship between the specialization and division of labor in industrial unit and professional ethics.

- There is a direct relationship between gender and professional ethics.

- There is a direct relationship between job stability and professional ethics.

- There is a direct relationship between the degree of adherence of people to the doctrines and religious belief and observance of professional ethics. 


\section{Theoretical Definitions}

- Commitment: This concept is used about sense of duty to pursue special work or search for a specific purpose. The result of this feeling is that freedom of choice and the number of alternatives of social actions will be limited. (Azdanloo, 2005, pp. 198-199)

- Work: The work means to accomplish tasks that require mental and physical effort spent to provide goods and services for human needs. (Giddens, 2007, pp. 540-541)Colson also says: "Work is using material and spiritual force in producing wealth or services. Henry Bergson writes about human activity that "human work will create suitability". "Thus, in the definition of work, the trait of suitability should be considered.(Tavassoli, 2006, pp. 8-9) In Marx point of view, work is a wise process accompanied with a previous plan.

- Occupation: Every form of employment with a wage that one regularly works. (Giddens, 2007, pp. 1008-1009) Job or career is a work done for regular and constant wage or salary; and in all cultures is the foundation of economy. (Giddens, 2007, pp. 542-543)

- Religion: a set of ideas that members of a community are committed to and include symbols that can be viewed with awe and respect and also the rituals and ceremonies where members of the community participate.(Azdanloo, 2005, pp. 1012-1013) According to Marx, religion is the heart of the heartless world, and a shelter against violence on daily reality (Giddens, 2004, pp. 502-503).

- Income: payments are usually caused by wages, salary or investment (Giddens, 2004, pp. 800801).

- Profession: The most common application of profession means vocation, occupation and business. The other component is authority in employment. Profession is an optional work. Some define the profession as productive activities for the staffs against wage (cash and material) with free desire done professionally and efficiently. . (Gharamaleki, 2009, pp. 6-7)

- Division of Labor: dividing a productive system into specialized tasks or jobs that causes a mutual dependency (Giddens, 2007, pp. 992-993).

- Job/career security: rapid changes can cause instability, the staffs of all kinds of jobs feel job insecurity, and it means the fear of the future security of their position and their role in the work environment (Giddens, 2007, pp. 590-591).

- Informal relations: in informal relationships, organization members know each other and personal relationships are established between them. In the informal structures, sometimes we can find informal ways to allow people to solve the issues that cannot be solved with official laws and regulations (Tavassoli, 2006, pp. 135-136).

- Professional Ethics: Professional Ethics is a branch of applied ethics that examines ethical issues in the profession. Professionals have two expectations from Ethics: systematic expression of moral responsibilities in profession and effective diagnosis and resolution of ethical issues (Gharamaleki, 2009, pp. 11-12).

\section{Methodology}

In this research, questionnaires, interviews and observation were used to collect data. This study' statistical population includes all the employers and employees working in industrial zones No. 1 and No.2 of Ardabil. Their number, according to the latest information received from the Social Security Administration of Ardabil province, is 3000 people. $(\mathrm{N}=3000)$

Stratified sampling is appropriate in this case, samples were randomly chosen for statistical population, primarily from the industrial units that were active, semi-active and less active located in the Industrial zones No. 1 and No.2, relating to the share of the working people. 
To estimate the sample size, the Cochran formula of determining sample size was used that sample size was determined $n=400$. SPSS software was used for data analysis. In this case, appropriate to type and level of variables for descriptive data, descriptive index, median, mean, variance, and standard deviation are used and for analytical data, the indicators of the Chi-square analysis, ANOVA, regression, analysis of variance, correlation coefficients and path analysis are used.

\section{Findings}

Table 1: Distribution of respondents according to income

\begin{tabular}{|c|c|c|c|c|}
\hline Variable values & frequency & percentage & Valid percentage & $\begin{array}{c}\text { Cumulative } \\
\text { percentage }\end{array}$ \\
\hline $300000-200000$ & 65 & 16.2 & 16.2 & 16.2 \\
$500000-300001$ & 227 & 56.6 & 56.6 & 72.8 \\
$700000-500001$ & 93 & 23.2 & 23.2 & 96 \\
$1000000-700001$ & 10 & 2.5 & 2.5 & 98.5 \\
1000000 & 6 & 1.5 & 1.5 & 100.0 \\
Total & 401 & 100.0 & 100.0 & \\
\hline
\end{tabular}

In the above table, the highest frequency (227) belongs to the respondents with the income between 300001 to 500000 Tomans, which is close to $56.6 \%$ of the sample size. The other important (93) frequency belongs to the respondents whose income is between 500001 to 700000 Tomans which is close to $23.2 \%$ of the sample size. Regarding the variable in the table that is interval scale, index of central tendency was mean that its value is equal to the amount of wages between 300001 to 500000 Tomans according to law of labor.

Table 2: Distribution of respondents in terms of intimate relationships between workers

\begin{tabular}{|c|c|c|c|c|}
\hline Variable values & frequency & percentage & Valid percentage & Cumulative percentage \\
\hline So much & 2 & .5 & .5 & 100.0 \\
\hline much & 12 & 3.0 & 3.0 & 99.5 \\
\hline average & 63 & 15.7 & 15.7 & 96.5 \\
\hline little & 175 & 43.6 & 43.6 & 80.8 \\
\hline Very little & 149 & 37.2 & 37.2 & 37.2 \\
\hline Total & 401 & 100.0 & 100.0 & \\
\hline
\end{tabular}

The most frequency (175) belongs to the respondents who assess the intimate relationship effect on the professional ethics little. 43.6 percent is devoted to this group. Frequency (149) belongs to the respondents who announce the effect of intimate relationships on professional ethics very little and $37.2 \%$ of the sample has been allocated to them. Frequency (63) belongs to the respondents who select the average item and have 15.7 percent of the sample. According to the type of variable table that is interval scale, Central Tendency Index of the table is the median and belongs to little option. 
Davoud Abdollahi et al., International Journal of Organizational Leadership, Vol. 1 No. 2 (2012)

Table 3: Distribution of respondents in terms of expertise and responsibility (division of labor)

\begin{tabular}{|c|c|c|c|c|}
\hline $\begin{array}{c}\text { Variable } \\
\text { values }\end{array}$ & frequency & percentage & Valid percentage & Cumulative percentage \\
\hline So much & 29 & 7.2 & 7.2 & 100.0 \\
\hline much & 33 & 8.2 & 8.2 & 92.8 \\
\hline average & 111 & 27.7 & 27.7 & 84.5 \\
\hline little & 140 & 34.9 & 34.9 & 56.9 \\
\hline Very little & 87 & 21.7 & 21.7 & 21.9 \\
\hline 0 & 1 & .2 & .2 & .2 \\
\hline Total & 401 & 100.0 & 100.0 & \\
\hline
\end{tabular}

The most frequency of the table (140) belongs to respondents who announce the effect of division of labor and specialization of professional ethics little and make up 34.9 percent of sample size. Frequency (111) belongs to the respondents who announce the effect of division of labor and specialization of the professional ethics average and 27.7 percent of sample size belongs to this group. Frequency (87) belongs to the respondents announce the division of labor and specialization of professional ethics very little and $21.7 \%$ of the sample belongs to this group. Depending on the variable in the table that is ordinal scale, Central Tendency Index of the table is the median and belongs to little option with a frequency of 101 .

Table 4: Distribution of respondents by gender

\begin{tabular}{|c|c|c|c|c|}
\hline Variable values & frequency & percentage & Valid percentage & Cumulative percentage \\
\hline men & 263 & 65.6 & 65.6 & 65.6 \\
\hline women & 138 & 34.4 & 34.4 & 100.0 \\
\hline Total & 401 & 100.0 & 100.0 & \\
\hline
\end{tabular}

In this table, the frequency (263) belongs to the men respondents. They accounted for $65.6 \%$ of the sample. (138) of the respondents are women, who accounted for 34.4 percent of the sample. According to the type of variable table that is Nominal Scale, Central Tendency Index of the table is the mode and belongs to men option with a frequency of (263).

Table 5: Distribution of respondents in terms of job stability

\begin{tabular}{|c|c|c|c|c|}
\hline Variable values & frequency & percentage & Valid percentage & $\begin{array}{c}\text { Cumulative } \\
\text { percentage }\end{array}$ \\
\hline Completely agree & 2 & .5 & .5 & 100.0 \\
\hline agree & 11 & 2.7 & 2.7 & 99.5 \\
\hline average & 41 & 10.2 & 10.2 & 96.8 \\
\hline disagree & 160 & 39.9 & 39.9 & 86.5 \\
\hline $\begin{array}{c}\text { Completely } \\
\text { disagree }\end{array}$ & 187 & 46.6 & 46.6 & 46.6 \\
\hline Total & 401 & 100.0 & 100.0 & \\
\hline
\end{tabular}

In the above table, the highest frequency (187) belongs to the respondents who are completely disagree with the impact of job stability in professional ethics, these groups make up $46.6 \%$ of the sample size. Frequency (160) belongs to the respondents who disagree with the direct impact of job stability in professional ethics and 39.9 percent of the sample has been allocated to them.41 people assessed the direct impact of job stability on professional ethics average, and $10.2 \%$ of the sample belongs to this group. The median is the average option with frequency of 46.6 . 
Davoud Abdollahi et al., International Journal of Organizational Leadership, Vol. 1 No. 2 (2012)

Table 6: Distribution of respondents in terms of adherence to religious beliefs

\begin{tabular}{|c|c|c|c|c|}
\hline Variable values & frequency & percentage & Valid percentage & Cumulative percentage \\
\hline So much & 164 & 40.9 & 40.9 & 100.0 \\
\hline much & 167 & 41.6 & 41.6 & 82.5 \\
\hline average & 41 & 10.2 & 10.2 & 92.8 \\
\hline little & 21 & 5.2 & 5.2 & 98.0 \\
\hline Very little & 8 & 2.0 & 2.0 & 100.0 \\
\hline Total & 401 & 100.0 & 100.0 & \\
\hline
\end{tabular}

In the above table, the highest frequency (167) belongs to the respondents who announce their adherence to their religious beliefs much and accounted for $41.6 \%$ of the sample size. Important frequency of (164) belongs to the respondents who assessed their religious beliefs rate very much and make up 40.9 percent. Frequency (41) belongs to the respondents who announced average level of their religious beliefs and have evaluated nearly 10.2 percent of the sample size. Depending on the variable in the table that is ordinal scale, Central Tendency Index of the table is the median and belongs to average option with a frequency of 41 .

\section{Analyzing the research hypothesis}

Table 7. interpreting two-dimensional tables and research findings

\begin{tabular}{|c|c|c|c|c|c|c|c|}
\hline No. & Hypothesis & df & Significant & Chi-square & $\begin{array}{l}\text { correlation } \\
\text { coefficient }\end{array}$ & $\begin{array}{c}\text { sampl } \\
\mathrm{e}\end{array}$ & result \\
\hline 1 & $\begin{array}{c}\text { Relationship between } \\
\text { income and professional } \\
\text { ethics }\end{array}$ & $\mathrm{Df}=4$ & $\mathrm{Sig}=0 / 002$ & $\chi 2=403 / 725$ & $\begin{array}{c}\mathrm{R}=0 / 157^{* *} \\
\mathrm{Sig}=0 / 002\end{array}$ & 401 & $\begin{array}{l}\text { Confirm } \\
\text { the } \\
\text { hypothesis }\end{array}$ \\
\hline 2 & $\begin{array}{l}\text { relationship between the } \\
\text { intimate relationships } \\
\text { (friendship) and } \\
\text { professional ethics in the } \\
\text { workplace }\end{array}$ & $\mathrm{Df}=4$ & $\mathrm{Sig}=0 / 000$ & $\chi 2=309 / 012$ & $\begin{array}{l}\mathrm{R}=-/ 270^{* *} \\
\mathrm{Sig}=0 / 000\end{array}$ & 401 & $\begin{array}{l}\text { Confirm } \\
\text { the } \\
\text { hypothesis } \\
\text { reversely }\end{array}$ \\
\hline 3 & $\begin{array}{l}\text { relationship between the } \\
\text { specialization and } \\
\text { responsibility and } \\
\text { professional ethics }\end{array}$ & $\mathrm{Df}=5$ & $\mathrm{Sig}=0 / 000$ & $\chi 2=218 / 766$ & $\begin{array}{c}\mathrm{R}=-/ 389 * * \\
\mathrm{Sig}=/ 000\end{array}$ & 401 & $\begin{array}{l}\text { Confirm } \\
\text { the } \\
\text { hypothesis }\end{array}$ \\
\hline 4 & $\begin{array}{c}\text { relationship between } \\
\text { gender and professional } \\
\text { ethics }\end{array}$ & $\mathrm{Df}=1$ & $\mathrm{Sig}=0 / 039$ & $\chi 2=38 / 965 \mathrm{a}$ & $\begin{array}{l}\mathrm{R}=0 / 039 \\
\mathrm{Sig}=/ 433\end{array}$ & 401 & $\begin{array}{l}\text { Confirm } \\
\text { the } \\
\text { hypothesis }\end{array}$ \\
\hline 5 & $\begin{array}{c}\text { Relationship between job } \\
\text { stability and professional } \\
\text { ethics }\end{array}$ & $\mathrm{Df}=4$ & $\mathrm{Sig}=0 / 000$ & $\chi 2=376 / 743$ & $\begin{array}{c}\mathrm{R}=-/ 232 * * \\
\mathrm{Sig}=0 / 000\end{array}$ & 401 & $\begin{array}{l}\text { Confirm } \\
\text { the } \\
\text { hypothesis } \\
\text { reversely }\end{array}$ \\
\hline 6 & $\begin{array}{c}\text { Relationship between } \\
\text { religious beliefs and } \\
\text { observance of professional } \\
\text { ethics }\end{array}$ & $\mathrm{Df}=4$ & $\operatorname{sig}=0 / 000 \mathrm{~s}$ & $\chi 2=309 / 362$ & $\begin{array}{c}\mathrm{R}=/ 457 * * \\
\mathrm{Sig}=/ 000\end{array}$ & 401 & $\begin{array}{l}\text { Confirm } \\
\text { the } \\
\text { hypothesis }\end{array}$ \\
\hline
\end{tabular}

Table 1- Regarding the significance of chi-square $\chi 2=403.725$ at Sig $=0 / 002$ level, we will conclude there is a relation between two above variables, so $\mathrm{H} 1$ will be validated. On the other hand, there is a significant relation between workers income with work commitment. Significant relation of $\mathrm{R}=0.157 * *$ approves this claim. 
Table 2- Regarding the significance of chi-square $\chi 2=309.012$ at $\mathrm{Sig}=0 / 000$ with the hypothesized relationship between intimate relationships and commitment or work ethic, a significant reversal is confirmed, in other words, more rigid the relationships within the unit, more commitment rises.

Table 3- According to the calculated value of $\chi^{2}=218.766$ a score level that is significant, regarding this hypothesis, higher levels of job commitment are among those with more expertise. The correlation coefficient $\mathrm{R}=-/ 389 * *$ is significant, confirming the hypothesis. Inverse relationship between two variables implies that the higher the education level, lower commitment rate we have.

Table 4 - Due to the significance level of the chi-square $\chi 2=38.965 \mathrm{a} \operatorname{Sig}=0 / 039$, relationship between two variables of gender and professional commitment will be confirmed. In other words, gender plays a decisive role in the people's commitment. The relation $(=0 / 039 \mathrm{R})$ showed a weak relationship between them.

Table 6- Regarding the Chi-square $\chi 2=309.362 \mathrm{a}$, hypothesized relationship between religious beliefs and ethical principles are upheld. In other words, more the religious beliefs of the workers, they increase the level of commitment and professionalism.

\section{Regression analysis}

Model Summary

\begin{tabular}{|c|c|c|c|c|}
\hline Std. Error of the Estimate & Adjusted R Square & R Square & R & Model \\
\hline 7.49280 & .329 & .339 & .582 & 1 \\
\hline
\end{tabular}

a. Predictors: (Constant), MasoulateVTaghsos, GENSIYYAT, Samamanekargar, Tahsilat, Sobateshogle, Eteghadat, Daramad

ANOVAa

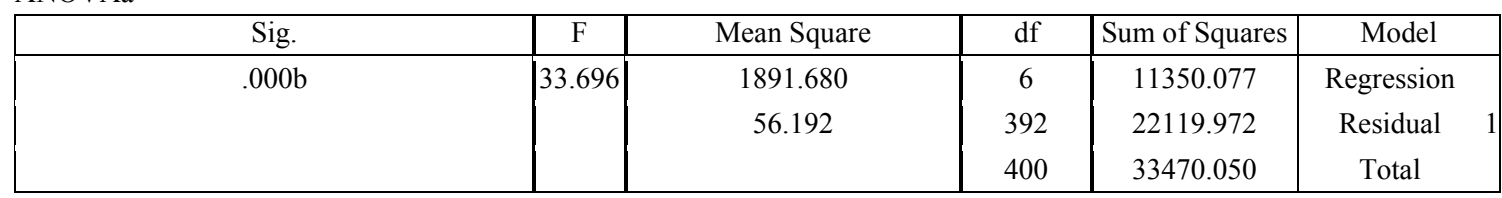

a. Dependent Variable: taahhod123

b. Predictors: (Constant), MasoulateVTaghsos, GENSIYYAT, Samamanekargar, Tahsilat, Sobateshogle, Eteghadat, Daramad,MohitKar

Coefficientsa

\begin{tabular}{|c|c|c|c|c|c|}
\hline \multirow{2}{*}{ Sig. } & \multirow{2}{*}{$\mathrm{T}$} & Standardized Coefficients & \multicolumn{2}{|c|}{$\begin{array}{c}\text { Unstandardized } \\
\text { Coefficients }\end{array}$} & \multirow{2}{*}{ Model } \\
\cline { 3 - 6 } & & Beta & Std. Error & $\mathrm{B}$ & \\
\hline & & & 2.332 & 85.041 & (Constant) \\
.000 & 1.249 & .055 & .843 & 1.053 & GENSIYYAT \\
.041 & 2.053 & .090 & .516 & 1.060 & Daramad \\
.000 & -8.199 & -.367 & .436 & -3.573 & Eteghadat \\
.236 & -1.187 & -.055 & .528 & -.626 & Sobateshogli \\
.058 & -1.904 & -.089 & .519 & -.988 & Rabet dostane \\
.000 & -7.110 & -.305 & .344 & -2.447 & Thaselat \\
\hline
\end{tabular}

a. Dependent Variable: taahhod123

As shown in regression Table, the correlation coefficient of regression is $R=0 / 582$, and the coefficient of determination is $\mathrm{R} 2=0 / 339$, in other words $33 \%$ (percent) of the changes are in the 
dependent variable (work or professional ethic) in manufacturing units in Industrial zones No.1 and No.2 in Ardabil and the rest changes are under the influence of exogenous variables of the model.

ANOVA table data or analysis of variance is significant. Table III beta coefficient (the rate of change of each independent variable on the dependent variable) based on default ENTER to arrange for variables is:

$055 / 0=$ gender $\quad 0 / 367=$ religious beliefs $\quad-0 / 305=$ Specialization and Education $-0 / 055=$ job stability $\quad-0 / 089=$ Intimate relationships $\quad 0 / 090=$ income

Regression equation for given data is as follows:

Commitment to religious beliefs + job stability + intimacy in workplace + Specialization $+E(0 / 292)$

In other words, the set of independent variables included in the assumptions of the study only affected on 30 percent of workers commitment and 70 percent of other factors have been influenced by variables that are not included in the assumptions.

\section{Conclusion}

In this paper, the relationship between "work ethic" and "social factors associated with it" among workers in the industrial zones No.1 and No.2 of Ardabil was studied. The results show that the rate of compliance with work norms and professional commitment in the community is relatively high. Studying independent variables in our case study (industrial zones No.1 and No.2 of Ardabil), indicates that there is a significant relation between income and work ethic of workers. It seems that immaterial incentives like insuring the job stability of workers by employers are more related to their work commitment than income. . This is important and can be considered by employers and units owners. There is a significant relationship between religious beliefs and commitment of the workers. Mechanisms to strengthen the religious beliefs of workers (like a number of courses to strengthen their religious beliefs and clergymen inviting to lecture on professional ethics, respecting people's rights and properties, importance of earning lawful money and trusteeship, etc.) are important. The findings of one of the hypotheses suggest that another important factories intimate and emotional relations between workers and employer. As Scientific Management School and Humanist Relations School, Taylor studies and Elton Mayo in America (Tavassoli, 2000)show, informal and emotional relationships can have a significant impact on Increased sense of belonging and commitment to the working conditions of workers and consequently feeling of doing a valuable work. The fact is that the change in the workers attitude towards the rigid and formal relations in the manufacturing units is very important. For example, creating the right conditions for the participation of workers in decisionmaking processes, the quality of production line, working hours, wages and other similar facts can be very helpful. Another hypothesis was significant relationship between job stability and career commitment. High significance level shows the fact that worrying about the job prospect, work concerns and having a promising outlook of working in the manufacturing unit or not, is directly related to occupational commitment and compliance with professional norms.

The role of employer's threats on the probability of laying off or dismissal of workers for any reason cannot be disregarded. Feeling pessimistic about job prospects and its concerns, affects the sense of belonging and commitment of employee to his employer and hence on output (goods or services produced). Undoubtedly If parameter such as occupational concern (stability of job), be resolved for the workers of the manufacturing units, the improvement of performance, efficiency and consequently increase in the feeling of attachment and commitment can be expected. Not threatening the workers to lay off by the employer and support of insurance and related governmental 
organizations is effective in this issue. Weak relationship between gender and commitment in this study means that among the working men and women of the industrial zones, there is no significant difference in the pattern of job commitment. Such a finding was expected, regarding the nonindustrial city of Ardabil and lack of manufacturing units and consequently low average of the household incomes, in the few active and semi-active industrial units, both women and men are breadwinners, so they try to do the best job, and there is not a significant difference between them in terms of job commitment.

Disapproval of relationship between education and professional commitment suggest that because the frequency of workers having associate degree or less is more than other degrees, Due to the symmetrical perspective, there is no significant difference between the degrees of commitment. Finally, It seems that using the workers in working positions appropriate to their expert can be effective in increasing their professional commitment.

\section{Practical suggestions}

Without doubt, the main concern of the manufacturing firms is to increase efficiency and improve the quality and quantity of its output. This condition is fulfilled when workers and human resources do their best for the interests and goals of the unit. Such an important factor is not possible without sense of belonging and passion in workers. So the major problem that each small or large business faces is to strengthen the sense of belonging, and manifestation of this feeling in professional and working commitments. Speaking of commitment, compliance with norms and standards is expected from each manufacturing business and it's reflection on the output (goods and services) is considered. Based on the findings, to fulfill the commitment between workers of different manufacturing units, following are recommended: ensuring the job stability, not threatening the workers to be laid off, Improving working conditions in terms of environmental hygiene, levels of payments and wages, observing the rules and regulations of insurance for workers, enhancing the religious beliefs, social justice in payments and wages, human relations in the workplace, participation of the workers indecisionmaking at different stages and forms of productive activities, noticing the worker's point of view, Meritocracy system in a way that positions are given to workers fairly and based on their expertise. Applying the above can establish commitment and professional ethics in the workers of manufacturing units.

\section{References}

Abolhasan Tanhaei, H. (2010). Theories of Sociology. Tehran: Marandiz.

Alizadeh, A. R. (2004). A Sociological Approach to Iranian Labour Law. Private Law, 2(100).

Ashofteh Tehrani, A. (2010). Sociology of Work and Employment. Tehran: Bahman Borna publication.

Azdanloo, H. (2005). The Basic Definitions of Sociology. Tehran: Nashre Ney.

Barati Ahmadabadi, H., Oreizi, H. R., \& Nouri, A. (2010). Relationship Between Organization Climate and Work Conscientiousness with job performance. Journal of Applied Psychology, 4(1).

Boudon, R. (2008). The Classical Tradition in Sociology. (P. Bagher, Trans.) Tehran: nashr-e-markaz.

Chalabi, M.(2005). The Sociology of Order. Tehran: Nashre Ney.

Chalabi, M.(2006). Social Analysis in Action Space. Tehran: Nashre Ney.

Delaney, T.(2008). Classical Social Theory: Investigation and Application. (B. Sadighi, \& V. Toloui, Trans.) Tehran: Nashre Ney.

Ebadollahi Chanzanagh, H., \& Jafar, N. (2010). Values and Work Ethics: Case Study of Teachers in Rasht. Iranian Social Studies, 4(3).

Fiuzat, E. (2002). Youth attitudes to profession and industry. Iranian Journal of Sociology, 4(1). 
Davoud Abdollahi et al., International Journal of Organizational Leadership, Vol. 1 No. 2 (2012)

Gharabaghi, H., \& Garoosi Farshi, M. T. (2009). Relationship Between the Five Factor Model of Personality and Job Satisfaction in Employees of Tabriz Tractor Manufactory . JOURNAL OF EDUCATION AND PSYCHOLOGY, $4(2)$.

Gharamaleki, A. F. (2009). Occupational Ethics in Iranian and Islamic Civilization. Tehran: Institute for Cultural and Social Studies; Ministry of Science, Research and Technology.

Gharamaleki, A. F. (2010). Applied Ethics in Islam and Iran. Tehran: Institute for Cultural and Social Studies; Ministry of Science, Research and Technology.

Gholipour, R., zareematin, H., jandaghi, G., Emami, M., \& Rastegar, A.(2009). Survey of Appropriateness Between Jobemployed and its Influence on Organizational Commitment of Staff (The Case Study in National Refining and Distribution of Oil Company in Iran). Organizational Culture Management, 7(20).

Giddens, A. (2004). Sociology. (M. Sabouri, Trans.) Tehran: Nashre ney.

Giddens, A. (2007). Sociology. (H. Chavoshian, Trans.) Tehran: Nashre Ney.

Golparvar, M., \& Oreizi, H. R.(2009). Meta-Analysis of the Relationships among the Dimensions of Organizational Commitment and Job Alternative, Tendency to Remain and Turnover. DANESHVAR RAFTAR, 1(33).

Liaghatdar, M. J., Bakhtiari Nasrabadi, H., Samiee, F., \& Hashemi, B. V. (2011). The Study of Efective Factors on Work Commitment. JOURNAL OF APPLIED SOCIOLOGY, 22(1).

Marx, K. (2008). Economic and Philosophic Manuscripts of 1844. (H. Mortazavi, Trans.) Tehran: Agah Publications.

Najar Nahavandi, M., \& Tavassoli, G. A. (2009). A Study on Work Ethic. Women in Development \& Politics, 6( 22).

Oreizi Samani, H. R., Zaker Fard, M. S., \& Nuri, A. Q. (2009). The Relationship of Career with Job Power and Organizational Commitment: A Case Study of Male and Female Personal of Research and Development Units of Industrial Companies. WOMENS STUDIES, 7(1).

Raymond, A. (2003). Main currents in sociological thought. (B. Parham, Trans.) Tehran: Elmi - Farhangi Publications.

Ritzer, G. (2003). Sociological Theory. (M. Salasi, Trans.) Tehran: Elmi Publications.

Sabouri, M. (2004). Sociology of Organizations. Tehran: Shabtab.

Safarnia, H. (2011). Investigation of the Effective Factors on Creation and Enforcement of Organizational Commitment among the Public Bank Staff. MANAGEMENT RESEARCH IN IRAN (MODARES HUMAN SCIENCES), 15(2).

Saiedian, N., \& Moradi, M. (2009). The Relation Between Bass Styles Leadership with Principal's Work Conscious in Boy High Schools in Isfahan City. Curriculum Planning, A Quarterly Journal Of Science and Research, 1(22).

Tavakoli Khomeini, N. (2003). Industrial Sociology. Tehran: Payamane Noor University.

Tavassoli, G. A. (2006). Sociology of Work and Profession. Tehran: SAMT .

Tavassoli, G. A. (2007). Sociological Theories. Tehran: SAMT.

Thompson, k. (2009). emile durkheim. (S. Mosama Parast, Trans.) Tehran: Nashre Ney.

Ziaee Bigdeli, M. T. (2010). Survey on Job Quality at Industrial Organization of Tabriz Towns. Journal of Applied Sociology the University of Isfahan, 21(1). 